\title{
HATÁRON TÚLI ELHUNYT HÍRES MAGYAR NEMESÍTŐINK
}

\author{
Matuz János
}

\begin{abstract}
Absztrakt: A külföldön jelentős sikereket elért magyar növénynemesítők és alkotásaik idehaza alig ismertek. E cikk közülük a közelmúltban elhunyt nemesítök (Linner Bertalan, Veneny Lajos, Bartalos Menyhért, Rákóczi Lajos, Szamák István, Berényi János és Derera Miklós) életét és munkáságát ismerteti. Ök számos növényfaj pl. szőlő, gabona, dinnye, lencse, köles, tökfélék, gyapot, dísznövény stb. nemesítésével jelentősen hozzájárultak hazájụk növénytermesztésének fejlesztéséhez.

Abstract: The significant successes achieved abroad Hungarian plant breeders and their works are hardly known in Hungary. This article describes recently deceased breeders' (Bertalan Linner, Lajos Veneny, Menyhért Bartalos, Lajos Rákóczi, István Szamák, János Berényi and Miklós Derera) life and work. They have contributed significantly to the development of crop production of their country with breeding of several species e.g. grapes, corn, melon, lentil, millet, cucurbits, cotton, paprika, ornamental plant etc.
\end{abstract}

Kulcsszavak: növénynemesítés, növénynemesítök, szőlö, búza, dinnye, tökfélék, gyapot

Keywords: plant breeding, plant breeders, grapes, wheat, melons, cucurbits, cotton

\section{Bevezetés}

A növénynemesítés jelentösége a köz- és politikai gondolkozásban nem eléggé ismert, noha élelmiszereink többsége, használati dolgaink (ruházatunk, eszközeink stb.) jelentős része, környezetünk, tájaink szépsége (virágok, parkok, erdök, szölészetek, gyümölcsösök stb.) közvetlenül, vagy közvetve a növénytermesztés eredményei, s mivel túlnyomórészt nemesített növényeket termesztünk, a háttérben mindig ott van a nemesítői tevékenység. Sajnos a nemesítők gyakran nem közismertek, s különösen így van ez a határainkon túl tevékenykedő nemesítök esetében. Ezért e cikknek az célja, hogy ismertté tegye a határainkon kívül élt, néhány híres magyar nemesítő életét, munkásságát. Kik is ők?:

- Linner Bertalan (1886-1969) sebész, szőlö, Beregszász, Kárpátalja

- Veneny Lajos (1888-1975) gabona, dinnye Sóssziget, Szlovákia

- Bartalos Menyhért (1924-1999) gabona, cirok, dinnye, Sóssziget, Szlovákia

- Rákóczi Lajos (1929-2012) búza, hibriddinnye, cirok, Sóssziget, Szlovákia

- Szamák István (1920-2010) búza, zab, lencse, köles Diószeg, Szlovákia

- Berényi János (1954-2015) tökfélék, alternatív növények, Újvidék, Szerbia

- Derera Miklós (1919-2011) búza, gyapot, dísznövény, Ausztrália.

\section{Linner Bertalan}

Linner Bertalan sebészorvos (1. ábra) 1887-ben született Beregszászon, iskolába, gimnáziumba is ott járt. Budapesten végezte el az orvosi egyetemet, és 1911-ben avatták orvossá. Az első világháborúban harctéri sebészként több kitüntetést is kapott. A háború után 1919 júniusában visszatért Beregszászra és haláláig ott élt és dolgozott. 60 éves sebészi tevékenysége során több mint 46 ezer mütétet végzett, 
azokról pontos nyilvántartást vezetett. Az elsők között volt Európában, aki szívmütétet mert végezni.

\section{1. ábra: Linner Bertalan}

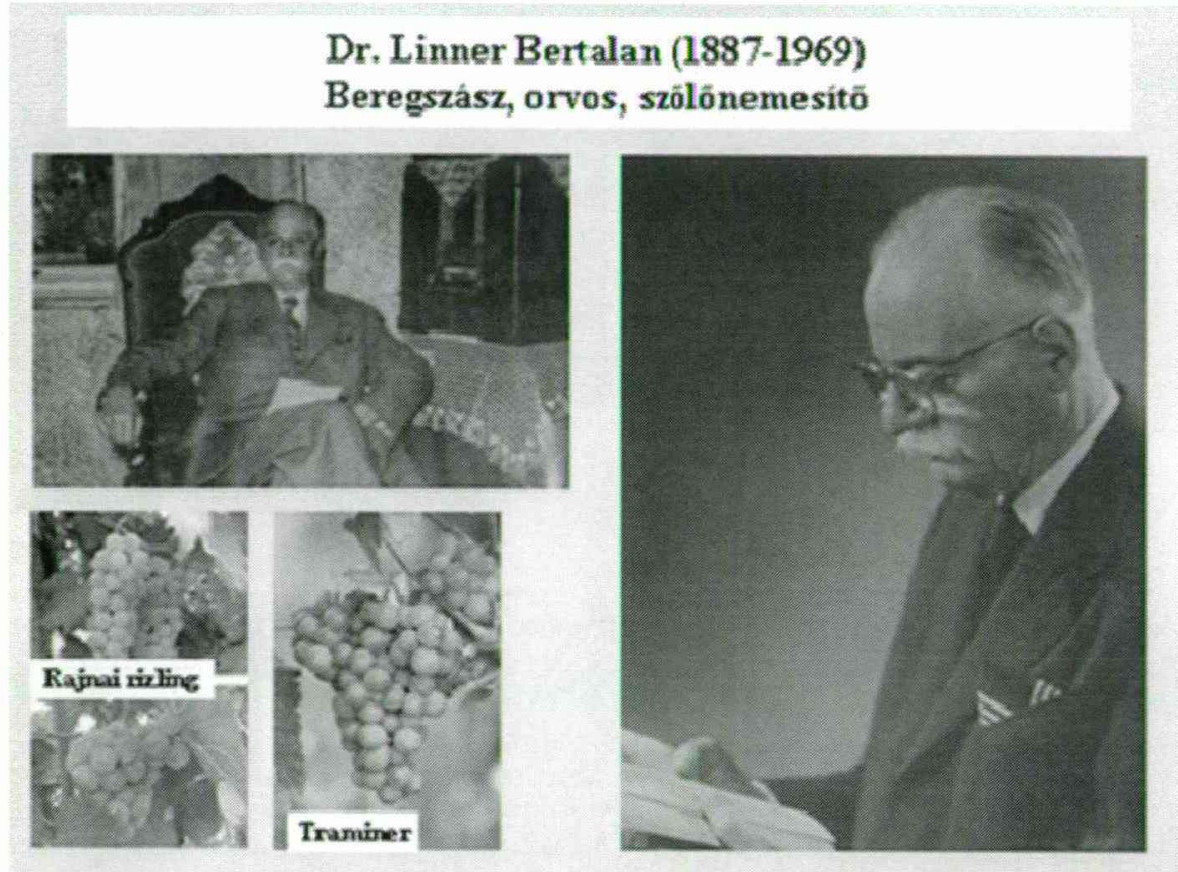

Forrás: a szerző gyűjteményéből (2016)

Szabadidejében a szőlőnemesítéssel foglalkozott, és kapcsolatban állt a Pécsi Szőlészeti Kutató Intézettel. Szőlöjében több mint 100 fajta nemes szőlöt termesztett. Borai messze földön híresek voltak. A Rajnai Rizling és a Traminer keresztezéséből származó hibridet róla nevezték el. Sajnos ültetvénye az 1970-es években a tủz áldozata lett és nagyon sok, általa nemesített fajta odaveszett. Parászka György benei szőlész-borásznak sikerült megmenteni Linner Bertalan által nemesített szőlők egy részét, úgy, hogy a Pécsi Szőlészeti és Borászati Kutatóintézet génbankjából öt, Linner által nemesített fajtát visszahozott szülőföldjükre, a Bereg-vidékre.

Szegény sorsú betegeitől soha nem fogadott el tiszteletdíjat, keresetének nagy részét a római katolikus templomra költötte. 1969-ben, a templom sekrestyéjében, mise közben érte a váratlan halál. A Kórház utcát Beregszászban Linner Bertalanról nevezték el, a Vérke-parti öregdiákok emléktáblát avattak tiszteletére szülöháza és a gimnázium falán, a kórház kertjében közadakozásból mellszobrot állítottak a tiszteletére (2. ábra). 


\section{2. ábra: Linner Bertalan mellszobra Beregszászon}

\section{Dr. Linner Bertalan (1887-1969) Beregszász, orvos, szôlônemesítő}

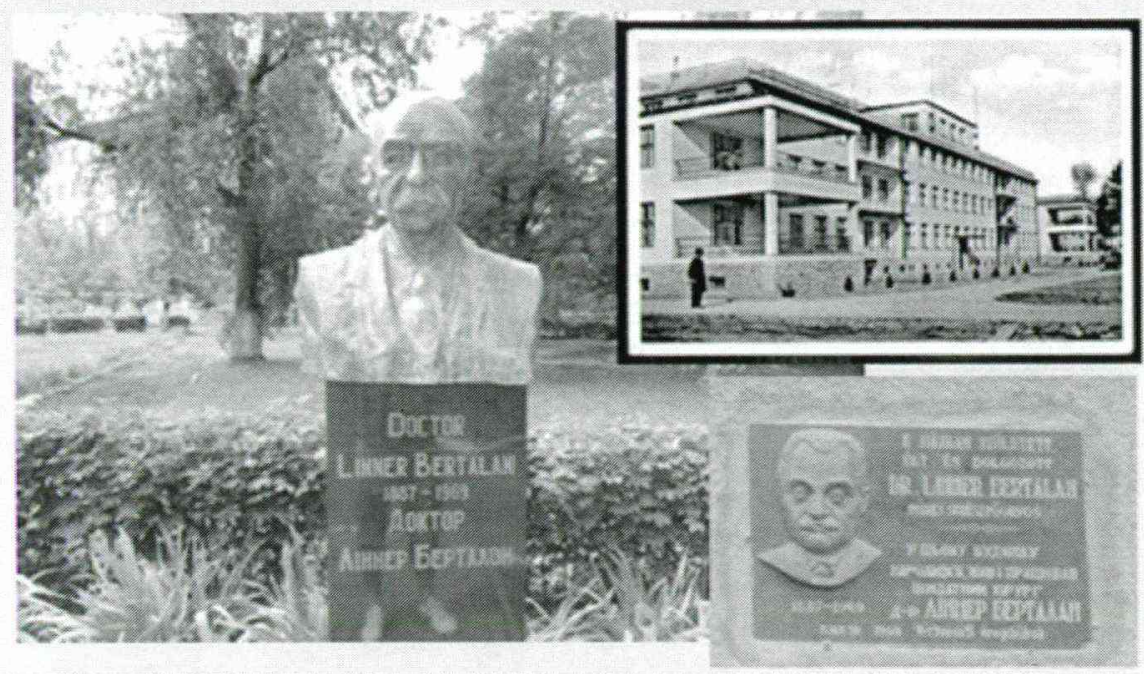

Forrás: a szerző gyűjteményéből (2016)

\section{Veneny Lajos}

Veneny Lajos (3. ábra) 1888-ban Csavajó községben született. Az elemi iskolába szülőhelyén, középiskolába Privigyén és Nyitrán járt. Ezután a Kassai Magyar Királyi Akadémián tanult és 1910-ben agronómus lett. Gyakornoki éveit Szomolányon töltötte, nemesítői pályáját 1913-ban kezdte Mosonmagyaróváron, ahol Grábner Emil vezetésével, burgonyával és búzával foglalkozott. Az I. világháborúban, 1916-ban orosz hadifogságba esett. A tomszki fogolytáborba vitték, de a növénynemesítést ott is folytatta; rendszerezte a szibériai búzafajtákat. 1917-ben Veneny Lajos kikerül a táborból és intézeti munkatársként dolgozott az Omszki Nyugat-Szibériai Kísérleti Állomáson a nemesítő, genetikussal Nyikolaj Vavilovval és az igazgató Talanovval. Veneny fó feladata a szibériai búzák rendszerezése volt, de a tavaszi durum búza hibridizációval és burgonyával is foglalkozott. Annak ellenére, hogy megbecsült nemesítőként dolgozott, honvágyának engedve 1921-ben hazatért. A rimaszombati járásban kezdett dolgozni, fölhasználva saját szibériai gyüjteményét. A következő években szerte a mai Szlovákia területén, magán- s egyházi birtokokon, nemesítő állomásokat alapít, és elkezdte a cirok- és dinnyemagvakat gyüjtését alapanyagnak.

A második világháború után a nemesítői törzsanyag a Gomba (Hubice) községi állami gazdaság kezelésébe került, ahol Veneny lett a vezető, munkatársa pedig Rákóczi Lajos nemesítő. Gabona, cirok, és dinnye nemesítésén dolgoztak. Mivel a gombai terület talaja nem volt megfelelő a szintén nemesítésben dolgozó Bartalos 
Menyhérttel együtt megbízást kaptak megfelelőbb termőterület keresésére. Ezt 1952-ben Sósszigeten találták meg. Veneny Rákóczival és Bartalossal megalapítja a Sósszigeti Növénynemesítő Állomást (ma Istropol Solary a.s. néven működik a cég). Veneny közben lemondott a vezetői pozícióról, de 1962-ig aktívan főnemesítőként, 1968-ig pedig tanácsadóként segítette a növénynemesítési munkát. 1972-ben Nyitraföre (Kl’ačno) költözött, 1975-ben ott hunyt el.

\section{3. ábra: Veneny Lajos dinnyenemesítő}

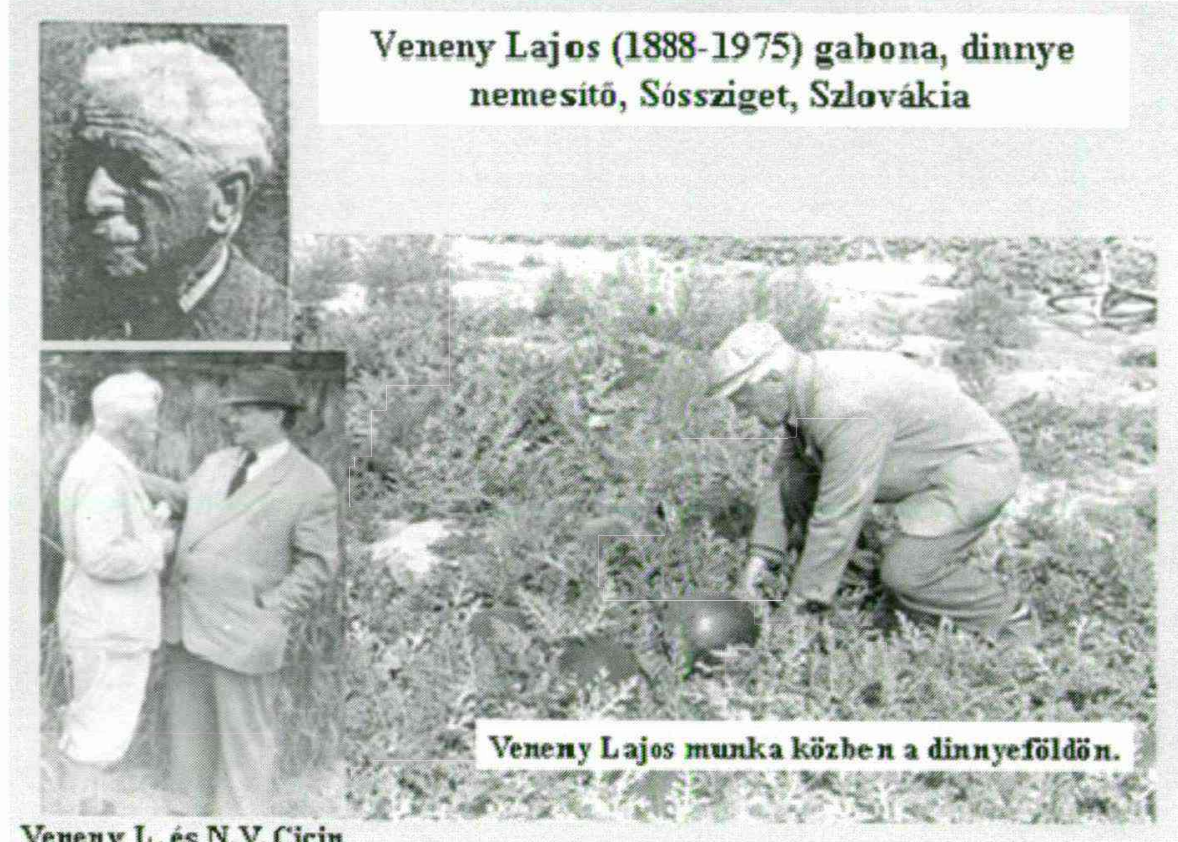

Venery L.és N.V.Cícin

Forrás: a szerző gyüjteményéből (2016)

Veneny Lajos a minőséget ill. a beltartalmi értéket fontosnak tartotta: Ő vezette be a nemesítésben búzaliszt minősítését, és a dinnye C-vitamin és a karotin tartalmának növelését. Öt őszi, három tavaszi búzát, egy tavaszi árpát nemesített ki, a nevéhez füződik továbbá a zöld húsú Solartur sárgadinnye és a Dunaj görögdinnye nemesítése. Ö hozta létre elöször az árpa sima toklászos és csupasz magvú botanikai különlegességeit és az első durum búzát Szlovákiában. Rendszeresen publikált a Szabad Földmüvesben.

Magánemberként nagy művészetpártoló és lelkes mủgyüjtő volt. Felfedezője és mecénása volt Szabó Gyula festőmủvésznek. Különleges szokásairól egykori munkatársai igen érdekes történeteket meséltek róla nekem. Díjak: "Kiváló munkáért” állami kitüntetés. Születésének 100. évfordulója alkalmából (1988) emlékérmet adtak ki. 1990-ben a sósszigeti Nemesítő Állomáson ünnepélyesen felavatták és megnyitották a „Veneny Lajos emlékszobát”. 


\section{Bartalos Menyhért}

Dr. Bartalos Menyhért (4. ábra) 1924-ben Tejfaluban született, az elemi iskolát ott, a polgári iskolát Somorján végezte, a győri felső kereskedelmi iskolában 1943-ban érettségizett. A háborúban fogságba esett és hadifogolyként Franciaországban bányász volt.

A mosonmagyaróvári Agrártudo-mányi Főiskolán 1949-ben szerzett oklevelet. 1949/50: magángazda, majd deportált földműves Holics-ban. 1950-1952-ben a gombai Növénynemesítő Állomás techniku-sa, ezt követően a sósszigeti Nemesítő Állomás munkatársa, 1961-től vezető növénynemesítője, 1982 és 1992 között vezetője volt. Öt búzafajtát, négy új takarmánycirok-fajtát és négy dinnyefajtát nemesített. Kiváló agrotechnikus volt, elévülhetetlen érdemei vannak az intenzív búzatermesztési technológiák meghonosításában és elterjesztésében. 1983-ban Klement Gottwald államidíjat kapott a szlovákiai búzatermesztés színvonalának emelése terén kifejtett munkásságáért. Életéről két portréfilm is készült (SZTV, 1983; MTV, 1988). Fő mủvei: 1. Növeljük a szántóföldi takarmányok termését. 2. A cirok termesztése. 3. A hímsterilitás kihasználása a takarmánycirok heterózisos nemesítésében.

\section{4. ábra: Bartalos Menyhért}

\section{Bartalos Menyhért (1924-1999)}
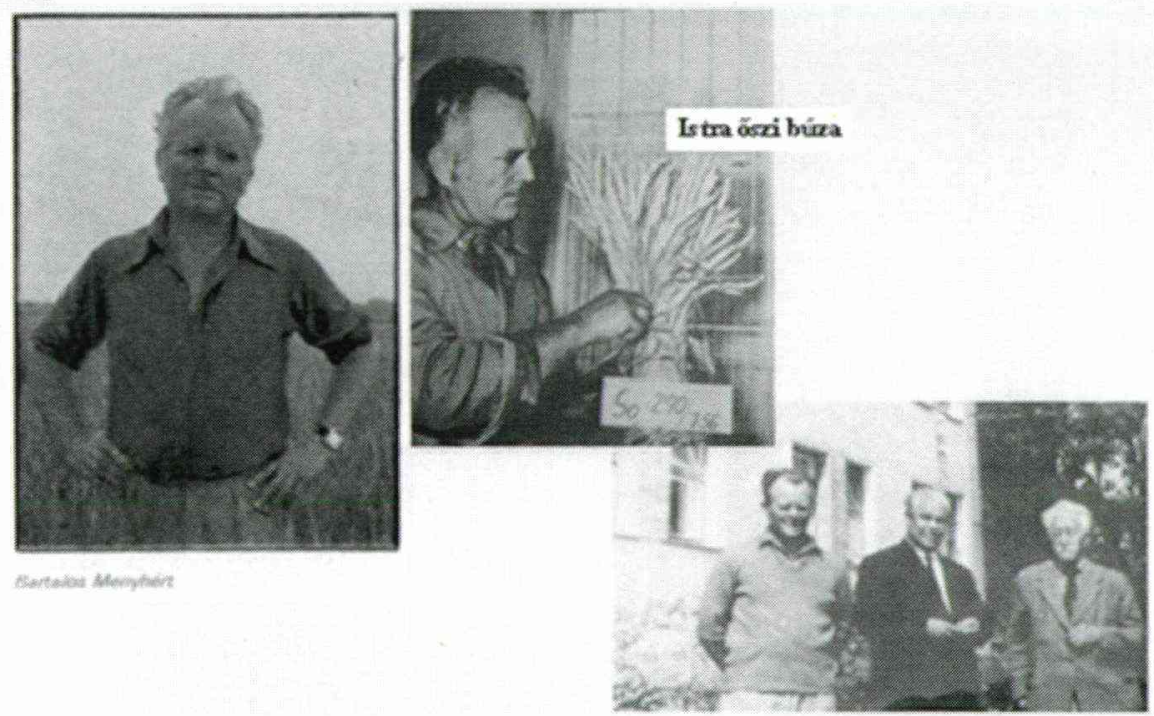

Bartabs M. Remesab VN., Venery I.

Forrás: a szerző gyüjteményéből (2016)

\section{Rákóczi Lajos}

Rákóczi Lajos (5. ábra) életét Csibrányi Zoltán írása alapján ismertetem. Rákóczi Lajos Kéty községben született 1929-ben. Elemi iskolás évei után Budapesten járt 
polgári iskolába. Majd - már dolgozó évei alatt, az 1960-as években - a Nyitrai Mezőgazdasági Főiskolán nemesítői szakképesítést szerzett.

1945-tỏl az egyházi birtokon működő anyalai nemesítő állomáson Veneny Lajos mellett dolgozott, mint szakmunkaerő. 1948-tól, az államosítás után a gombai nemesítỏ állomáson, mint nemesítő technikusként dolgozott, egészen 1951ig. 1951-1953 között kötelező katonai szolgálati idejét töltötte. 1953 novemberétől a sósszigeti nemesítő állomás növénynemesítője lett. Sósszigeten 1978-tól főnemesítő volt egészen 1990-es nyugdíjba vonulásáig. Imádta munkáját, és akkor érezte jól magát, ha a földeken, a kézzelfogható nemesítést végezhette. Hosszas, súlyos betegség után bekövetkezett haláláig Dunaszerdahelyen élt, és az ottani temetöben helyezték örök nyugalomra 2012-ben

Több évtizedes szakmai munkássága során foglalkozott a takarmánycirok és az őszi búza nemesítésével és fajtafenntartásával. Veneny nyugdíjba vonulásakor, 1962-től átvette a a dinnyenemesítést, és fajtafenntartást. Főnemesítőként 5 görögdinnye hibrid, 2 cukordinnye hibrid, 1 cukordinnyefajta és 1 cukorcirok hibrid, társnemesítőként 6 őszi búzafajta, 4 takarmánycirok fajta, 1 görögdinnyefajta, 1 sárgadinnyefajta örzi munkája nyomát. Csehszlovákiában ő volt az első nemesítő, aki hibrideket is nemesített. Az első görögdinnye-hibridjei a Lajko F1 és a Melko F1 voltak, az első sárgadinnye-hibridje pedig a zöldhúsú Solar F1 volt. Számos szakmai és ismeretterjesztő-népszerüsítő cikket írt a dinnye, a takarmánycirok és az őszi búza termesztésének és nemesítésének a problematikáiról.

\section{5. ábra: Rákóczi Lajos}

\section{Rákóczi Lajos (1929-2012)}
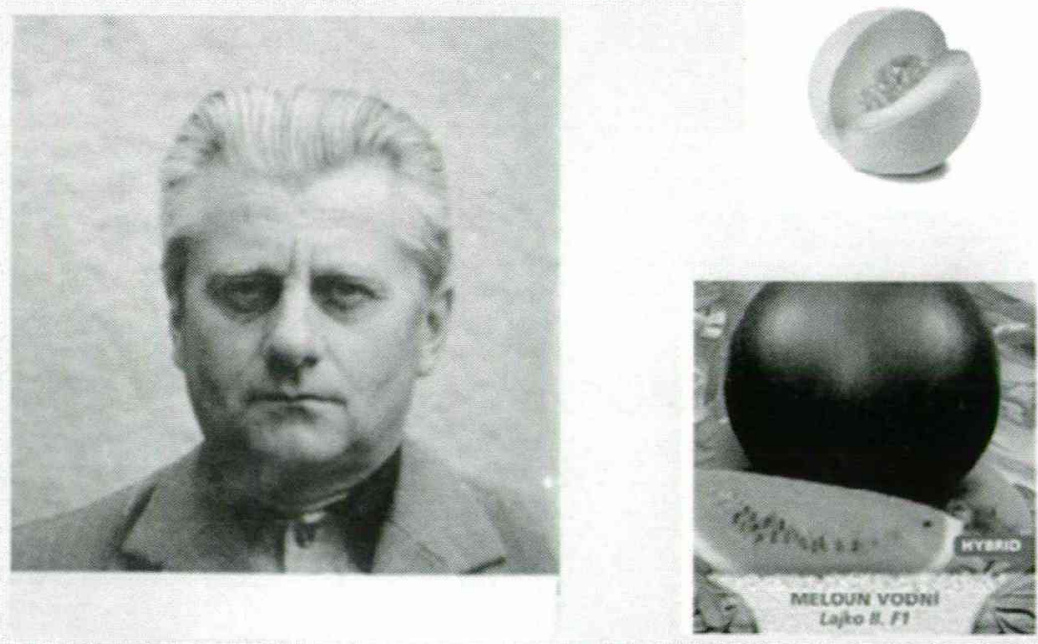

Forrás: a szerző gyűjteményéből (2016) 


\section{Szamák István}

Szamák István (6. ábra) orvos családból származott, 1920-ban Pozsonyban született, ott kezdett el iskolába járni. Már az iskolában jó alapokat kapott, megtanult magyarul, németül, szlovákul és késöbb további nyelveket is elsajátított. A gimnázium végeztével már nyolc nyelvet ismert - a magyart, németet, szlovákot, csehet, angolt, finnt, franciát és a latint, amikor én megismertem már tíz nyelven volt tárgyalóképes. A gimnázium után Mosonmagyaróváron, a mezőgazdasági akadémián tanult. Befejezése után a pozsonyi Komenský Egyetemre járt, ahol biológiai és kémiai tanulmányokat folytatott. A „Hétszer hét év búzanemesítés” címü önéletrajzi írásában, 75 éves korában azt írta magáról: „17 tanulóévemből 16 és felet magyar nyelven hallgattam, de még egy napig sem voltam Magyarország polgára. 3+1 éven át Mosonmagyaróváron, mint külföldi hallgató tanultam, 1943tól 1945 húsvétjáig, mint külföldi állampolgár munkaengedéllyel dolgoztam az akkor Magyarországhoz tartozó Diószegen. Munkahelyemen megmaradtam, s nem volt semmilyen háborús veszteségünk, ebben volt egy kis részem. 1945-ben beidéztek a községházára: akarok-é szlovák lenni. Mondtam: nem! Akkor számítsak azzal, hogy majd kiköltöztetnek. .... 1947-ben elhatározták, hogy kitelepítenek. Pozsonyban a munkahelyem igazgatóságán azonban úgy döntöttek, hogy nekem az a kötelességem, hogy a Tátra alatt Lomnicán burgonyanemesítő telepet indítsak, és hogy ők elboronálják; a kitelepítés addig lezajlik."

A diószegi növénynemesítőben kezdett el dolgozni, ahol fönemesítőként 1943 szeptemberétöl (elsö fönöke Friedrich Béla volt) 1993-ig dolgozott, több mint 50 éven át. Nyugdíjba 71 éves korában vonult. Már karrierje kezdetén híressé vált, mivel neki köszönhetően, sikerült a háborúban több biológiai anyagot megmenteni, elsősorban őszi búzát, tavaszi árpát, borsót, kukoricát és más terményeket.

Félévszázados nemesítôi munkája igen termékeny volt: 5 búza, 1 zab, 1 lencse, 1 köles, 1 árva rozsnok és egy tarajos búzafü fajta. Több mint tízezer keresztezést végzett, a búzák közül csak a szálkásakat kedvelte, és ezért csak szálkás búzákat nemesített. 1983-ban ő is Klement Gottwald állami díjat kapott a szlovákiai búzatermesztés színvonalának emelése terén kifejtett munkásságáért.

Ahhoz, hogy az ember eredményes munkát végezhessen, szükséges a biztos és megértő családi háttér is. Ezt felesége, Lívia teremtette meg a számára, újhelyi, majd galántai otthonukban. 62 éven keresztül éltek együtt, és az egyik új búzafajtát őróla nevezte el. Mindketten elöbb a Vox Humana (1969-1986) később a galántai Kodály Zoltán Daloskör lelkes, hüséges tagjai voltak 1985-től 25 éven keresztül. A növénynemesítés mellett a mủvészetnek, a zenének és az irodalomnak szentelte idejét. Hosszantartó betegség után, 2010-ben hunyt el Galántán. „Széles érdeklődési körü, érdekes ember volt. Otthonában könyvekkel, fényképekkel, az unokák, dédunokák rajzaival vette magát körül, szobájának mennyezetén pedig Finnország térképe..., ez az otthon máig e kiváló ember személyiségét sugározza", írta róla a Galántai Újság. 


\section{6. ábra: Szamák István}

\section{Szamák István (1920-2010)}
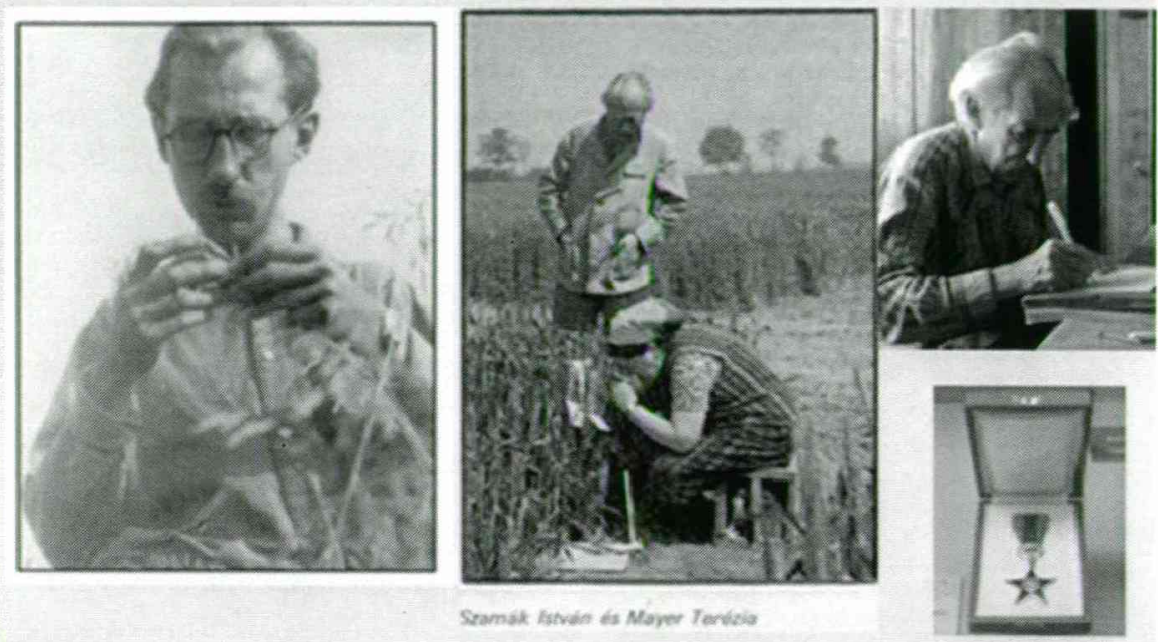

Forrás: a szerző gyüjteményéből (2016)

\section{Berényi János}

Berényi János (7. ábra) 1954-ben született Tordán. Az Újvidéki Egyetem Agrártudományi Karán 1979-ben növényvédő agrármérnökként végzett, majd 1990-ben itt lett a mezőgazdasági tudományok doktora, genetika és növénynemesítés szakterületen.

1990-től az Újvidéki Mezőgazda-sági Kutatóintézet kutatója, és az Intézet petrőci (Backi Petrovac) kutatóállomásának vezetője volt haláláig.

Föleg az alternatív növények nemesítésével foglalkozott: tök-, cirok- és kölesfélék, kender, dohány, csicsóka, olajlen, amaránt valamint az energianövények genetikájával, és a hagyományos és organikus nemesítéssel, vetőmagtermesztéssel. Összesen 38 fajtát állított elő 10 alternatív növényfajból, amiket Szerbiában és más országokban is termesztenek.

A Budapesti Corvinus Egyetem Kertészettudományi Kar Kertészmérnöki Szak Határon Túli Levelező Tagozatán, Zentán a Genetika és Növénynemesítés, valamint a Biotechnológia tantárgyak konzulens tanára volt. A belgrádi Megatrend Tudományegyetem rendes egyetemi tanára Genetika, Növénynemesítés és Vetőmagtermesztés tantárgyakból, amelyeket magyar és szerb nyelven oktatott. Magyar nyelvủ oktatói tevékenységének jelentősége, hogy lehetővé tette a szerbiai magyar kisebbség anyanyelven történő oktatását a szerbiai felsőoktatásban. 
Tudományos publikációinak, konferencia előadásainak száma 343, népszerúsítő cikkeinek száma meghaladja az 500-at. Munkásságából kiemelhető két kötet, egy önálló mủ és egy monográfia.

Számos tudományos társaságnak, egyesületnek és bizottságnak volt tagja, elnöke vagy elnökségi tagja: Szerbiai Genetikusok Szövetsége, Szerbiai Növénynemesítők és Vetőmagtermesztők Társasága, az EUCAPIA Cirok Szekció (Sorghum Section, Barabás Zoltán Biotechnológiai Egyesület és az MNE tiszteletbeli tagja, Szerbia Növényfajta-elismerő Bizottság tagja, Szerbia Biológiai Biztonság Szakértöi Tanácsának tagja SEEDNet (Délkelet-európai Növényi Genetikai Erőforrások Fejlesztési Hálózat), Iparinövények Munkacsoportjának elnöke (2004-2012).

Az MTA külhoni köztestületi tagja, az MTA által létrehozott Vajdasági Magyar Akadémiai Tanácsnak alapítója és elnöke. A magyarországi intézetekkel kialakított sikeres együttműködésért Teichmann Vilmos Díjban részesült (Debrecen, 1999). Kiemelkedő felsőokta-tói tevékenységéért a Budapesti Corvinus Egyetem díszdoktorrá avatta (2009). 2014-ben az MTA Arany János díjjal tüntette ki.

\section{7. ábra: Berényi János}

\section{Berényi János (1954-2015)}

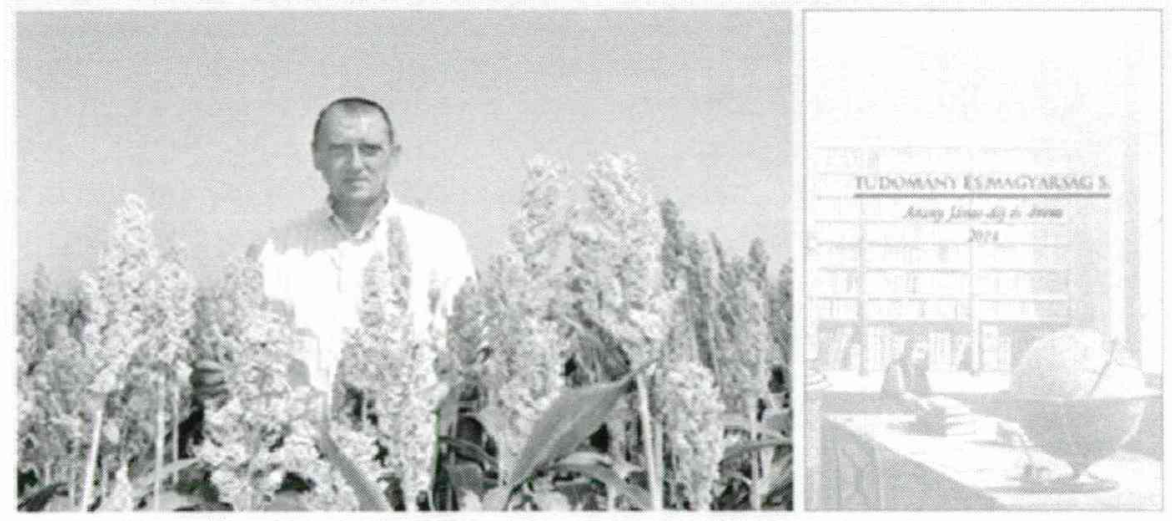

Berênyi Janos az elmuilt evtizedekben wơgzett munkajdval jelentós szolgalatot tett a magyar tudomanyossag multietnikumu környezetben töritnó fojlesztésęnek; kutatoi, oktatbi es tudomanyszervezöi tevokenységevel eredményesen szolgallta a magyar ês az cgyetemes tudományosságot, crösitette a szerbiai magyar kòzösséget.

Forrás: a szerző gyüjteményéből (2016)

\section{Derera Miklós}

Derera Miklós (8. ábra) 1919-ben született Budapesten. A József Nádor Müszaki és Gazdaságtudományi Egyetem Mezőgazdasági karán diplomázott. Ezt követően 
fiatal növénynemesítőként először a Monori Magnál, később Mauthner Ödön vetőmag vállalatánál tevékenykedett. Később, az ötvenes évek elején, vezető állásokban a Földművelésügyi Minisztérium különböző vállalatainál volt alkalmazásban. Ö irányította Székkutason a gyapotnemesítési kutatásokat, mely tapasztalatok oly fontosakká váltak későbbi életében.

Az 1956-os forradalmat követően emigrált, és 1957 szeptemberében Ausztráliába került, mint menekült. Pár hónapig gyári munkás volt, majd kertészeti laboratóriumi asszisztensként dolgozott. 1958-1961-ig New South Wales Földművelésügyi Minisztériumának Intézetében kutató agronómus lett, ott dolgozta ki, hogy hol és hogyan lehetne gyapotot termelni a régióban. Ez idő alatt döntő szerepet játszott a gyapottermelés létrehozásában a gyapotnak megfelelő talajok és gyapotfajták kiválasztásával. A Nandewar hegyláncon felfedezte a róla elnevezett gyapotfajt (Gossypium nandewarense Derera).

Rövid idő alatt nagy népszerüségre tett szert, s a farmerek Nick Dereraként hívták.

1957/58-ban Ausztrália 52 millió font értékben importált gyapotot, és néhány év múlva több mint 1 milliárd és jelenleg 2,2 milliárd dollár értékben exportál gyapotot. A Sydneyi Egyetem meghívására 1961-ben a NSW állam északi részén lévő Narrabriban - abban az évben alapított búzanemesítési intézetben - kezdte meg 20 éves búzanemesítői pályafutását és 1973-tól hosszú ideig igazgatója is volt az intézetnek. A búzakutatásokban is a gyapotéhoz hasonló sikereket ért el. Munkatársaival több, mint 10 új búzafajtát állított elö, melyek közül számos elterjedt a termesztésben nagy területen.

A sikeres fajta előállítás mellett intézetében jelentős módszertani fejlesztéseket is végeztek: gépesítették a tömegszelekciót, világelsőként vezettek be korai szelekciós technikákat a kalászban csírázás elleni nemesítésben. E témában hetvenes évek elején egy nemzetközi együttmúködést indított, ez volt elindítója a négyévente több száz résztvevőt vonzó tudományos konferenciának, az International Symposium on PreHarvest Sprouting in Cerealsnak is. Több mint száz publikációt írt, ő szerkesztette a „Preharvest Field Sprouting in Cereals” címü, 1989-ben az USA-ban megjelent alapmunkát (CRC Press, Inc., Boca Raton, Florida, US).

1981-ben, 62 évesen ment nyugdíjba, de azután is rendkívül aktív volt, nyugdíjasként is több paprika és dísznövény fajtája kapott Ausztráliában állami elismerést. Egykori munkahelyén 2011-ben bekövetkezett haláláig tudományos tanácsadóként tevékenykedett, elsősorban kertészeti területen, s tartotta a kapcsolatot, cserélt nemesítési anyagot kutató társaival szerte a világon, így velünk, magyarokkal is.

Munkássága elismeréseként számos kitüntetésben részesült. Pályájának talán legnagyobb elismerése volt, amikor a Brit Királynő 1994 júniusában az Ausztrál Rend tagjává fogadta.

A most bemutatott kiváló magyar nemesítökre, tudósokra méltán büszke lehet a magyar növénynemesítés, hiszen kreativitásukkal a kemény külföldi körülmények közt is ragyogó eredményekkel, új fajtákkal, hibridekkel 
gazdagították Kárpátalja, Felvidék, Vajdaság és Ausztrália növénytermesztését, kertészetét.

\section{8. ábra: Derera Miklós}

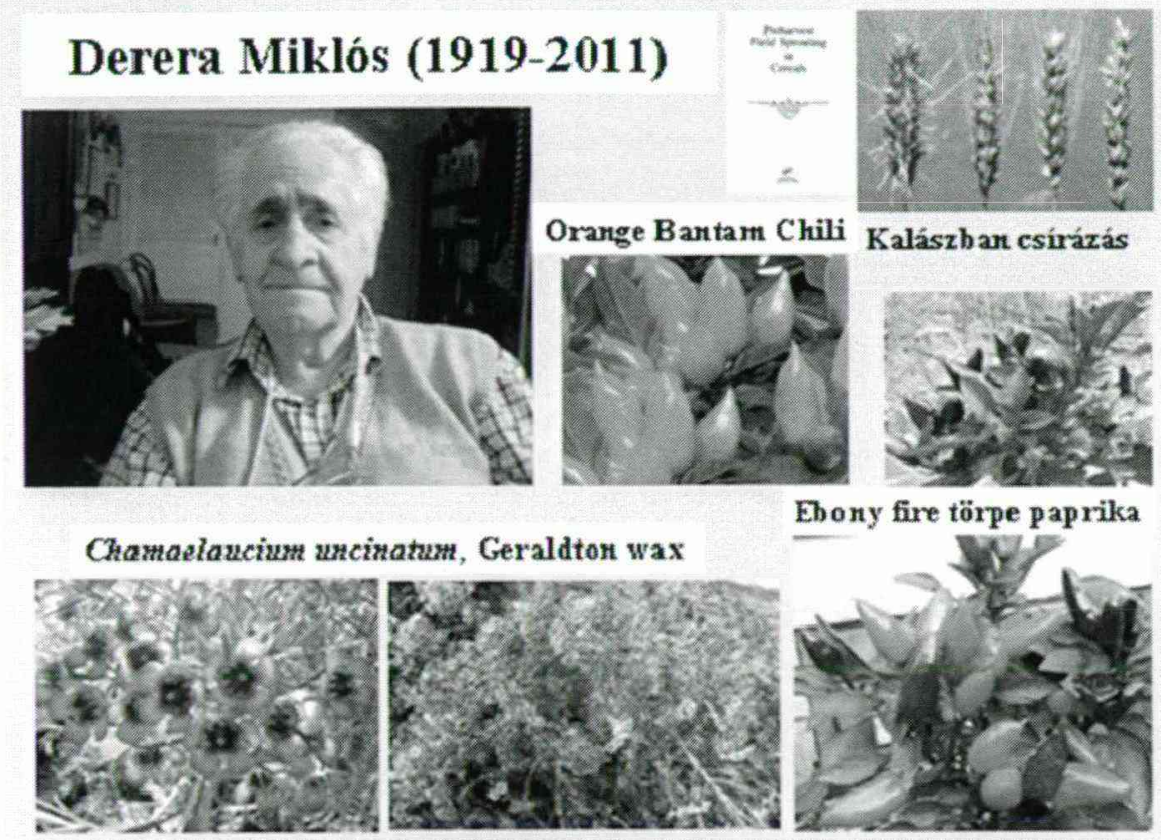

Forrás: a szerző gyűjteményéből (2016)

\section{9. Összegzés}

A most bemutatott kiváló magyar nemesítőkre, tudósokra méltán büszke lehet a magyar növénynemesítés, hiszen kreativitásukkal a kemény külföldi körülmények közt is ragyogó eredményekkel, új fajtákkal, hibridekkel gazdagították Kárpátalja, Felvidék, Vajdaság és Ausztrália növénytermesztését, kertészetét.

Köszönetek: Ezúton köszönöm Csibrányi Zoltánnak Rákóczi Lajosról küldött kéziratát és fotóit, Parászka Gergelynek Linner Bertalanról írt kéziratát és fotóit, dr. Zalabai Gyulának Bartalos Menyhértröl küldött fotóit.

A cikk a 2015. augusztus 18-án, Kecskeméten tartott „Alföldi kenyér, szőlő és bor, a Kárpát medence kincsei - határon innen és túl” címü konferencián elhangzott elöadás szerkesztett változata.

\section{Irodalomjegyzék}

Berényi J. (2014): Önéletrajz. Magyar növénynemesítők és eredményeik az ezredfordulón. (szerk.) Bóna et al. Kiadó: Magyar Növénynemesítők Egyesülete, Szeged.

Bóna L., Somogyi N. (2009): Prof. Nicholas F. Derera is 90 years old. Cereal Research Communications, 37:(2), 311-312.

Bóna L., Somogyi N. (2012): Búcsú (Derera Miklós). Vetömag, 2012/1, 11. 
Bóna L., Somogyi N. (2012): Derera Miklós (Nicholas F. Derera) (1919-2011). Növénytermelés, 61. 137-139.

Bóna L., Matuz J., Mesterházy Á. (2011): In memoriam Szamák István. Cereal Res. Communications, 39:(2), 315-316.

Csibrányi Z. (2013): A növénynemesítés professzora. National Geographic Magyarország, 2013. dec. 17.

Csibrányi Z. (2014): A növénynemesítés professzora (Veneny Lajos). Agroinform, 23:(2), 24-25.

Csibrányi Z. (2015): Rákóczi Lajos (1929-2012), kézirat.

Derera M.: <http://www.mozsa.hu/dynamic/amcv03_ang.pdf>. (2015.08.18.)

Görföl J. (1983): „Aki nem szívós” (Szamák István). A Hét 2. sz. 12.

<http://adatbank.sk/lexikonok/a-csehszlovakiai-magyarok-lexikona-1918-tol/\#lex>. (2015.08.18.)

$<$ http://archiv.mnt.org.rs/72-dr-Berenyi-Janos>. (2015.08.18.)

$<\mathrm{http}: / / \mathrm{mta} . \mathrm{hu} / \mathrm{data} / \mathrm{cikk} / 12 / 29 / 71 / \mathrm{cikk}$ 122971/Tudomany_es_magyarsag_5.pdf $>$. (2015.08.18.)

$<$ http://patents.justia.com/inventor/nicholas-f-derera>. (2015.08.18.)

<http://www.magyarszo.com/hu/2695/kozelet/126552/Dr-Ber\%C3\%A9nyi-J\%C3\%A 1 nosegyetemi-tan\%C3\%A1r-eml\%C3\%A9k\%C3\%A9re.htm.> (2015.08.18.)

$<$ http://www.vajma.info/cikk/tudomany/4198/MTA-kozgyules-Dr-Berenyi-Janost-kiemelkedotudomanyos-teljesitmenyeert-dijaztak-.html>

$<$ http://www.vajma.info/cikk/vajdasag/18552/Meghalt-Berenyi-Janos.html>

Keszeli F. (1983): Tartalmilag gazdag élet, Bartalos Menyhért. A Hét 1983/2, 11.

Matuz J., Bartalos M. (1991): Veneny Lajos (Ludovit Veneny), Szlovákia növénynemesítésének úttörője. Növénytermelés 40. 89-90.

Ozogány E. (2014): Szamák István növénynemesítő. Pedagógusfórum, 13:(5-6), 23.

Parászka G. (2015): Linner Bertalan, kézirat.

Sudová E. (2010): Ing. Stefan Szamák (1920-2014) jeden z najuspesnejsich slovenskych slachtitelov. Zivot v Sládkovicovice, 18:(6), 5.

Sudová E. (2013): Szamak hul.pdf. <www.sladkovicovo.sk/wp-content/uploads/2013/08>

Szamák I. (1995): Hétszer hét év búzanemesités. Kézirat. 